\title{
The Lost Souls in Edwin Arlington Robinson's Short Poems
}

\author{
Kawther Mahdi Al-Zwelef ${ }^{1}$ \\ ${ }^{1}$ Faculty of Arts, Zarqa University, Jordan \\ Correspondence: Dr. Kawther Mahdi Al-Zwelef, Faculty of Arts, Zarqa University, Jordan. E-mail: \\ kawther48@yahoo.com
}

Received: February 29, $2012 \quad$ Accepted: April 2, $2012 \quad$ Published: July 1, 2012

doi:10.5539/ass.v8n8p182

URL: http://dx.doi.org/10.5539/ass.v8n8p182

\begin{abstract}
This paper deals with some of the short poems of the modern American poet Edwin Arlington Robinson. Robinson lived, wrote, and died during a critical period in America's history, and a turning point in its culture and literature; which was the late $19^{\text {th }}$ century and the early 20 th.

While other poets of his age were busy experimenting and innovating in forms of poetry, he kept trying to revive the, almost dead, romantic naturalistic tendency in poetry. To accomplish this mission, he became deeply concerned with the human psychology, and began exploring the human depths trying to offer the readers hints about the motivations behind man's traumas. His short poems suggest that the various kinds of modern life's entanglements were behind man's suffering.

His sketches, in the poems under discussion, are mostly of defeated, pathetic, and isolated individuals. Yet, the poet shows a deep understanding and sympathy towards these wretched characters; since he has gone through almost all of their same tormenting experiences.

Robinson historical significance to American poetry is not debatable no matter what may be his final stature as a poet. His readers, many of his fellow poets, contemporary critics, and even the President of the United States Theodore Roosevelt, admired and appreciated his excellent qualities. He even won three Pulitzer Prizes for his distinguished poetic contributions.
\end{abstract}

Keywords: the shattering of the American dream, loss of hope, the psychological analysis, the modern American defeated characters in Edwin Arlington Robinson's poetry

\section{Introduction}

American culture is an offspring of the European culture. Although it preserved the same European tradition, yet, its production differs due to the influences of the American environment and the difference in people's aspirations and backgrounds.

What drove the Americans to flee Europe was an impulse of escape from frustration and restrictions of tradition, in the hope of finding the' New World' of democracy, freedom, and happiness. A country, as Thomas Paine describes, "Not a place upon earth might be so happy as America" (Note 1). However, as usual with any evolutionary process, development of American culture brought with it many problems that became so pressing during the following centuries.

Industrialism, with all its importance to the prosperity of nations, created a gap between the past ideals and the newly industrial required realities and manners. As a result, the Americans failed to adjust themselves to the new realities, which resulted in the failing of American democracy. Social problems were apt to follow. With the appearance of industrial capitalism, a privileged leisurely class, a business class and a working class appeared. In addition to these classes, there were the enslaved Negroes and the other poor minorities living side by side with the others. Therefore, class inequality was growing gradually among the Americans.

The acceleration of technological advancement drove the Americans away from spirituality of the past, to a life more oriented to scientific progress.

The Civil War of 1861 added another burden to that society, and became a major cause of the cultural collapse in America. 
Although such changes might be devastating for the structure of any society, and might ,as well, bring with them feelings of defeat, loss of values, frustration, confusion, chaos, alienation, and disillusionment, yet, luckily this served as a fertile ground for the flourishing of a versatile, rich, and vital literature (Note 2).

During the late years of the 19th century and early years of the 20th, a generation of innovative writers succeeded in finding new points of departure in the content, language, themes, and forms of poetry, in order to cope with the changes that befell American life and culture (Note 3). Those poets used to cheer the unlimited possibilities of America. However, other modern poets did not follow the same line of innovation; they were disillusioned, on one hand, and innovative in their own way, on the other hand. Edwin Arlington Robinson, for instance, was conventional in forms, but he revived a New England distinguished tradition in poetry that was considered dead nearly by everyone. What he revived was the convention of the compassionate concern with human experiences; that praises with nostalgia and blames with apprehension. His themes were not the usual cold, remote themes recurrent in the poetry of his time, but the delightful, sympathetic interest in the genuine human emotions. In addition to these qualities, his use of witty and ironic vocabulary made him sound remarkably modern.

With the passage of time, the Americans came to realize that both their ideal "American Dream", and the humanistic principle which their civilization aimed to build itself, were both shattered. Serious problems appeared during the 2oth century, and the Americans were lost between two philosophies; one that tends to exalt personal freedom, individualism and material gain over thinking and spirituality, and the other philosophy of life was totalitarianism (Note 4). Some poets, like Walt Whitman, suggested that preservation of the American ideal depends on the growth of an appropriate "religious and moral character beneath the political and productive and intellectual bases of the States"(Note 5). Such reconciliation between material gain and democratic aspirations, not only proved far-fetched, but also created feelings of disappointment, maladjustment, and loss of faith in "Great America" and the pursuit of happiness; especially among the intellectuals.

Many early 20th century American poets attempted to solve the crises of culture; some by trying to form a better prophetic vision for the future, others by suggesting elements of social survival, still others by protesting against, and criticizing the standardized success that America worshipped during that period. A rich variety of poems were produced in America during the first half of the 20th century by exceptional poets, among whom Edwin Arlington Robinson was one of the best representatives of his age.

\section{Edwin Arlington Robinson (1869-1935)}

This poet lived to witness the drastic changes that industrialization and Civil War brought to American culture. An intelligent and intuitive poet, born in Gardiner, Maine, and educated at Harvard; which he left before graduation due to his family's bad financial situation. Unlike the idealistic and theoretical work of Thoreau and Emerson, who both wrote of their lives to enlighten others, Robinson's work was an expression of what he felt, saw, and believed. His poems were true exercises in personal expression and not a polished celebration of life and its highly glossed experiences- that was common in the works of the other poets of his time.

His philosophical perspective combines nostalgia for the ideal lost past of America, with a dark pessimistic view of life and of the coming future. His best poetic form during the early period of his work was the dramatic lyric, which he used in the short poems that appeared in The Man Against the Sky (1916). During the second phase of his career he turned to long narrative poems such as Lancelot (1920) and Tristram (1927). However, in both phases, his main concern was the tragic complexities of life and the psychological portraiture of burned out characters. His life was bleak, bitter, and full of problems such as: addiction to alcohol (1903-4) that ran in his family, poetic neglect, unrequited passion, and frustration. Nevertheless, he tempered this pessimism by the use of unexpected ironic twists, imagination, wit, and grim humour in his poems. This same pessimism made him a forerunner of the disillusioned generation of modern poets. Hence, his usual image as an unhappy, lonely, and desperate person who explores anxiety. Despite this distressing quality, so many critics and readers considered him the greatest living poet, and admired him for his dignity, reticence, concentration, single-mindedness, and endurance (Note 6). His early lack of professional success ended when his volume Captain Craig and Other Poems (1902) received a favourable review from his work's admirer; President Theodore Roosevelt in (1905).

\section{Robinson's Poetry}

Robinson's poetry explores the repressive life of the tormented modern Americans; those who live silently in despair because their creative genius is destroyed by neglect and misunderstanding-which has a parallel to the poet's own autobiography, or to members of his family and acquaintances. By doing this, Robinson proved himself a person in search for moral values and the light beyond illusion, not an emotional escapist. Nevertheless, Robinson was in no way a social reformer (Note 7), but a creator of suffering creatures who expose the 
malignancies of the modern American culture. Being deliberately local, Robinson set his characters' tales in the fictitious deteriorating New England town of 'Tilbury', which Robinson used as an emblem of the American dream went astray. Tilbury is not merely a setting; it could represent the most frequent antagonistic moral force to appear in the life drama of Robinson's characters.

Emerson once described the poet, in his essay "The Poet", as "the namer ....sent into the world to the end of a new confession, and the world seems always waiting for its poet" (Note 8). This applies perfectly to Robinson, who was chanting his own time and social circumstances as a true representative of his age.

Although Robinson's poetry was not as innovative as that of his contemporaries, yet, his naturalistic and realistic tendencies were refreshing. He and few of his contemporary poets "used everyday language to convey their view of the darker side of existence. They depicted human weaknesses, foibles, and vanities. But they also shared a deep sympathy for the plight of ordinary people in the real world"(Note 9.) Robinson himself affirmed that, to produce great poetry, one should rely on tradition and inspiration; explaining in an interview that his "theory of art is very simple, and is not new. The great bulk of art consists merely in the giving out of what has been absorbed from others. The best, however, is a miracle of sheer genius, producing what the world has never before had" (Note 10). What truly distinguishes Robinson as a modern poet, is being "the only American poetcertainly the only one of major status-interested exclusively in human beings as subject matter for poetry; in the psychological, motivational aspects of living, in inner life as it is projected upon the outer" (Note 11). Thus, if not an innovator, Robinson was at least an early participator in the new developments. A close look at his poetry clarifies this.

\section{1 "Miniver Cheevy"}

In his dramatic lyric "MINIVER CHEEVY"(from The Town Down The River, 1910), Robinson exposes the character of a small town embittered dreamer, who prefers the old romantic, heroic world to his present life:

Miniver Cheevy, child of scorn,

Grew lean when he assailed the seasons,

He wept that he was born

And he had reasons.

Miniver loved the days of old

When swords were bright and steeds were prancing

The vision of a warrior bold

Would set him dancing.

Miniver sighed for what was not,

And dreamed, and rested from his labors;

He dreamed of Thebes and Camelot,

And Priam's neighbors

Miniver mourned the ripe renown

That made so many a name so fragrant;

He mourned Romance, now on the town,

And Art, a vagrant.

Miniver seems to be a frustrated romantic idealist, who painfully juxtaposes the past idealism with the present materialism, and the world of art and romance against a world of vagrancy. He escapes from the world of ugly reality into daydreaming; from Tilbury, that bears the stamp of crassness and blindness, to the glorious and heroic cities of Thebes and Camelot. Miniver could be mourning the lost American great dream that was challenged by a set of new corrupt values, attitudes, and goals.

In the above lines, Robinson employs one of his most powerful techniques, which is' irony'. The irony lies in the fact that this modern misfit who lives on charity ("on the town"), not only dreams of a heroic elevated life beyond his reach, but claims to personify 'art' that has become abandoned and has lost its past glamour! The following lines support this point:

Miniver loved the Medici, 
Albeit he had never seen one;

He would have sinned incessantly

Could he have been one.

Miniver cursed the commonplace

Miniver might be an artist. His love of the famous Italian 'Medici' family could be for their power, and their love and patronage of literature, as well. Not only that, but this "child of scorn" would never have "cursed the commonplace" unless he considers himself a member of the artistic 'elite'. However, we have always to keep in mind Robinson's ironic overtone. These ironic accents, that Robinson enjoyed using, seem to lift his phrases above the argumentative matter.

As an artist, Miniver goes on mourning his unlived life by discussing the dilemma of the artist in a materialistic world that has lost touch with art, beauty, and heroism. He laments the futility of his dream, the absence of any inspiration for art, and his need of money:

Miniver scorned the gold he sought,

But sore annoyed was he without it;

Miniver thought, and thought, and thought,

And thought about it.

Minever Cheevy, born too late,

Scratching his head and kept on thinking;

Miniver coughed, and called it fate,

And kept on drinking.

It might seem silly to mention the word "thought" four times in two straight lines, but this use provided precisely the required humorous impression. It exposed the character's half-withheld inner drama. The poet Robert Frost comments on such an instance saying that Robinson's "theme was unhappiness itself, but his skill was as happy as it was playful (Note 12). Miniver's thinking and drinking could never bring him closer to understand the whole truth about the grand plan of the universe. Nevertheless, he kept on trying. It is true that frustration and defeat are heard as background music throughout the poem; yet, Miniver is enduring and might see one day a dim light at the end of his life's tunnel- just as Robinson himself did.

At the end of this psychological analysis of Miniver's character, we notice that Miniver rationalizes his failure because of fate that brought him in the wrong time. He seems to believe that some earthly occurrence in the past could have made all the difference. Although he does this with a sense of submission, yet, he is totally convinced that not achieving his goal and missing all the beauty of the past, was in no way his fault; but the world's.

Robinson succeeded in presenting Miniver as a humorous figure whom we laugh at and pity, but there is more scornful wit than delight in the laughter. He understood Miniver's intolerable daydreams, and the tragedy of that haunted man, as no other person could ever do.

\section{2 "Richard Cory"}

In "Richard Cory" (from The Children of the Night, 1897), a low class worker (using the collective 'we') presumably narrates the tragic history of an apparent success mystery man called Richard Cory. The narrator could probably be no other than Tilbury's community personified now to acquire the dramatic role of the speaker in this poem:

Whenever Richard Cory went down town,

We people on the pavement looked at him:

He was a gentleman from sole to crown,

Clean favored and imperially slim.

The man described above seems to be a symbol of material success: a romantic, refined, upper class person. He seems to have all that modern people wish for:

And he was always quietly arrayed,

And he was always human when he talked;

But still he fluttered pulses when he said, 
Good morning; and he glittered when he walked.

Common people seem to envy the wealthy Richard Cory, subscribe to his values and good manners, and consider him super human. Who would not admire a person who glitters like a jewel! Nevertheless, that inexplicable, irregular spasm and nervous confusion, that befalls him whenever he greets these people, disturbs this perfect image. With an incredible economy of words and lively characterization, Robinson continues this quick rhythmic four- quatrain poem describing this breath-taking human being as:

.......ich, yes richer than a king,

And admirably schooled in every grace:

In fine, we thought that he was everything

To make us wish we were in his place.

So on we worked, and waited for the light,

And went without the meat and cursed the bread;

And Richard Cory one calm summer night,

Went home and put a bullet through his head.

Why did Richard Cory choose a "calm summed night" to "put a bullet through his head"? Did his outwardly successful appearance hide a sort of spiritual darkness? Was it lack of faith or endurance that made him end his life this way? Did he discover that life is absurd and is worthless to live? Was he suffering silently from psychological issues such as isolation? While the nagging question remains: was he 'happy' at all? The poem suggests no answers to these questions, but one thing becomes clear after his suicide: that there was loss and emptiness at the core of that man.

Robinson portrays in this poem a case of failure beyond redemption. No inner salvation was possible, because Richard Cory's hidden agony culminated in utter despair. Cory was a lost soul because he had no sense of belonging as it seems. A man needs to feel wretchedly alienated from his self and disintegrated from his group, to find it easy to commit suicide. It could be that the weight of life bore so heavy upon Cory, that death looked attractive to him. This sounds just like the tragic life story of Robinson's brother Herman who committed suicide after some unsuccessful business investments, dying prematurely in 1893.

Robinson juxtaposes in this poem materialistic deceiving appearances to inner deprivation and bleakness. He portrays such dramatic ends as the result of dualism these characters inherited from materialism. He universalizes in this poem the unredeemable gap between the self and society that stands an obstacle in the way of feeling whole. Only the climax of 'suicide' can put an end to that dichotomy. He criticizes standardized material 'Success' that America worshipped; making it clear that wealth does not necessarily bring happiness, but creates at times alienation due to antagonism between the mystical inner reality and society. The speaker's impression, as concerning Richard Cory's perfect life, was false because each person has a different outlook on life

Despite his sympathy with the spirit, and bitter complaining against the trading of spiritual values and self-esteem, for material gain, Robinson never assumed in his poetry an obvious or immediate victory of the self over anti spiritual society. He strove to achieve a kind of unity of these two disintegrated aspects of man's existence. However, modern societies, including the American, believe the opposite; they usually regard man's adherence to social laws and assimilation to his social functions, as the first step of social development.

\section{3 "Eros Turannos"}

'Alienation' is one of the initial truths of man's existence for Robinson. However, the most severe case of alienation for him is not that from society, but that when man reaches the level of losing contact with his inner soul. This stage is an indication that man has hit the bottom, because this is the real perplexing dilemma of life. The wife in "Eros Turannos" (in The Man Against The Sky, 1916) is one of Robinson's most dramatic lonely souls. She endures the suffering and the dissatisfaction of living with a worthless man, only because she fears old age and loneliness:

She fears him, and will always ask

What fated her to choose him;

She meets in his engaging mask

All reasons to refuse him; 
But what she meets and what she fears

Are less than are the downward years

Drawn slowly to the foamless weirs

Of age, where she to lose him.

The mask he wears symbolizes deception and distrust, and suggests that he hides something from her. She realizes that he is not a trustworthy man; yet, this does not only repulse her but attracts her at the same time! Hiding her trouble by self-deception creates a discrepancy between the imperfect reality she actually lives, and the satisfactory vision she has for her life. By deceiving her own self, she reaches the highest level of alienation:

Between a blurred sagacity

That had power to sound him,

And love, that will not let him be

The Judas that she found him,

Her pride assuages her almost,

As if it were alone the cost.-

He sees that he will not be lost,

And waits and looks around him.

He knows she needs him, which makes him feel powerful. Robinson has given him the name of Eros Turannos intentionally, because it is the name of the domineering god of sensual love. What empowers him is her "blurred sagacity" that diminished her sense of self-appreciation. She knows she has lost more than her pride because of this Judas of a husband's disloyalty; she feels the pain of betrayal, yet, accepts and wills herself to failure as a helpless introspective Hamlet. She is the typical Robinsonian loser, who copes daily with frustration, entrapment, and loss without acting to attain her full potential:

A sense of ocean and old trees

Envelops and allures him;

Tradition, touching all he sees,

Beguiles and reassures him;

And all her doubts of what he says

Are dimmed with what she knows of days

Till even prejudice delays

And fades, and she secures him.

The irony here- or should one say the muted tragedy- lies in this woman's willful misconception of life and her role in it. Her supreme indulgence in self-deception, by saying that she has achieved the victory of 'securing' him, strikes the readers as sheer irony. However, since this is real life, the wife's attitude might be explicable. This, definitely justifies Robinson's belief in" the unknowable constants that govern the human being from within"(Note 13). We can feel somehow, and even understand, the pathos of the wife's situation.

This picture of domestic unhappiness, where the husband finds security in his wife's status in society, and comfort in her love that comes through her submission and humiliation of the self, emerges here as a familiar universal tragedy. This poem deals with the lives of people other than the poet and his circle, yet, Robinson presents the case with sympathy as usual. He does not patronize or dramatize but suggests, and regards the situation as common enough in American society. He even considers such an imperfection in the wife's attitude as human, and approaches her dilemma in a compassionate and understanding manner.

Robinson presented, in the above stanzas, the wife's personal and social motives to endure her ordeal rather than to live alone. However, he was in no way a revolutionary poet who would encourage or suggest any kind of mutiny against social institutions or functions. In fact, one of the main themes of this poem, in addition to those of alienation and loss of communication, is that of the necessity for social endurance. In most of these poems, Robinson was only trying to spot the conflict between his characters' experiences and their expectations in life.

Upon introducing and exposing her broken life's drama in the first three stanzas, the poem reaches the climax of the wife's inner suffering in the fourth stanza: 
The falling leaf inaugurates

The reign of her confusion:

The pounding wave reverberates

The dirge of her illusion;

And home, where passion lived and died,

Becomes a place where she can hide,

While all the town and harbor side

Vibrate with her seclusion.

"The falling leaf" symbolizes her painful downward decline. She is aware of the hard truth that her home has turned into hell "where passion lived and died", yet, she has to live it because she was, to a certain extent, responsible for its creation. Blinding herself to all the facts she saw, heard, and felt - including what the town was whispering- must have resulted in this. She sees the light, but cannot follow it; for personal, psychological, and spiritual needs. Giving the wife such complex traits made her character bubble with life; which is one of Robinson's powerful techniques.

In addition to "The falling leaf", the poem abounds with images of dissatisfaction, defeat, frustration, betrayal, estrangement, dimness, deterioration and even death in life. Louis O. Coxe remarks that:

"Adumbrated in the first stanza, certain images, whose latent Power and meanings are reserved until the final lines, have the function of motifs, repeated constantly as the poem opens out into suggestion. There are three such images or symbols: waves, trees, stairs leading down. Throughout, these symbols control and provide a center for the meanings possible to the poem, and from the mention of "downward years" and "foamless weirs" in the first stanza to the triple vision of the last four lines these elements recur, the same but altered" (Note 14).

Such a complex symbolic technique was one of Robinson's special virtues. The images of "waves breaking", "familiar tree", and "stairways" are once more employed in the last stanza.

The poem moves in the last stanzas from the personal to the general, and the speaker shifts from the wife to no other than the same collective "we" of "Richard Cory". Although the "we" seems to know all the secrets of such unbalanced marriages and is convinced that the couple's relationship is doomed to end " like a stairway to the sea/ where down the blind are driven", yet, the "we" decides not to interfere, and declares: "Meanwhile we do no harm". The distressed wife is left to face her fate and confront all the forces she has challenged by herself. Nevertheless, the poet's sympathy, compassion, and recognition are always present.

\section{4 "Mr. Flood's Party"}

Eros Turannos's wife and Richard Cory, and even Miniver Cheevy, were not the only lost characters in Robinson's poetry who were left alone to face their demons. Eben Flood, in "Mr. Flood's Party"(appeared first in The Nation magazine, 1920, and later in Avon's Harvest, 1921) is another pathetic, helpless, lonesome character. He is an old man controlled by a tragedy beyond repair, and is left to tackle it by himself.

The poem begins when Eben Flood returns to his hilltop house from the town below, after filling his jug with wine. He stops along the road to hold a party of one; inviting himself to drink and accepts the invitation. Drinking until the bottle is empty, Eben discusses throughout the poem his dilemma of alienation and the gulf created between his personal and his social self-due to old age:

Old Eben Flood, climbing alone one night

Over the hill between the town below

And the forsaken upland hermitage

That held as much as he should ever know

On earth again of home, paused warily.

The road was his with not a native near

The poem opens with the word "old", which immediately announces the poem's concern with old age and the passage of time. Since Robinson exploits both irony and pun heavily in his poetry, we cannot overlook his deliberate choice of the poem's protagonist name. The name ' Eben Flood' might suggest the "ebb" and "flow"; which could symbolically indicate a pattern of coming and going that is associated with the theme of the passage 
of time. Naming the main character thus, Robinson directly connects him to the theme of the poem. On the other hand, naming him 'Flood', while he is thirsty for communication, is strikingly ironic.

The first stanza shows that Robinson is juxtaposing the old man's solitary house, situated on the hilltop, with the populated valley below. Similar juxtapositions will keep recurring throughout the poem to depict the old man's state of loneliness, deprivation, and loss of communication.

Action in the whole poem could symbolize a journey of man's life. It begins and ends on a deserted road between two equally undesirable places; an unreceptive town and an empty house; or shall we say between his empty life and his grave! However, as the poem proceeds, the pathetic tone of the opening lines unexpectedly changes into a more playful, comic, shockingly strange, and more humanly fascinating tone. Upon discovering that communication with outer nature and society has become inaccessible, Mr. Flood decides to turn inward and converses with himself:

"Well, Mr. Flood, we have the harvest moon

Again, and we may not have many more;

The bird is on the wing, the poet says,

And you and I have said it here before.

Drink to the bird." He raised up to the light

The jug that he had gone so far to fill,

And answered huskily: "Well, Mr. Flood,

Since you propose it, I believe I will."

The "harvest moon" designates the beginning of autumn; which might be a metaphorical question about Mr. Flood's achievements at his old age. He is trapped between two extremes: either living with absolute loneliness, or communicating with himself. Thus, he chooses in his unwilling exile to hold an ironic party with himself, which is better than no company, is.

He does not expect to live much longer, hence the hint to the theme of 'Carpe Diem' in "The bird on the wing". This is an allusion to Omar Al Khayyam's lines: "The Bird of Time has but a little way, /To flutter and the Bird is on the wing." The poet properly links the themes of the transient nature of life's pleasures, to that of the passage of time; which are both essential to the stream of events at this stage of the poem.

Mr. Flood seeks solace in drinking, and it seems that liquor lifts his spirit up. He invites 'himself' to drink, and his companion alter ego responds to the invitation. Stephen Dunn remarks that Mr. Flood here demonstrates "the regular drinker's comic sense of self- imposed propriety. He needs to give himself Permission"(Note 15). This is one of Robinson's techniques to distract us from total disappointment, and plant a smile on one's face. The following stanza is the most figurative in the poem:

Alone, as if enduring to the end

A valiant armor of scarred hopes outworn,

He stood there in the middle of the road

Like Roland's ghost winding a silent horn.

Below him, in the town among the trees,

Where friends of other days had honored him,

A phantom salutation of the dead

Rang thinly till old Eben's eyes were dim.

Opening with "Alone" relates absolutely to the main theme of the poem. However, the allusion to Roland- the great knight who blew his horn too late to Charlemagne asking for help- does not seem to fit here. Unless, the poet was trying to say that Mr. Flood's call for rescue came too late, just like Roland's. William Pratt suggests that comparing Mr. Flood to two renowned literary figures: Omar Al Khayyam and Roland "imply a doubly ironic contrast: Mr. Flood's drinking alone in old age shows neither the Persian poet's lighthearted hedonism, nor the French knight's heroic martyrdom, but an ironic pathos at the end of life"(Note 16). Yet, a close reading of the stanza will confirm that it is not Roland who was evoked; but rather, his ghost winding a silent horn. Mr. Flood was calling his phantom friends from the dim and mute world of death as well. The call of both was not heard. 
In the next two stanzas, Mr. Flood goes on drinking to escape from his present ugly reality, to an imaginary world created by the help of his jug. The jug becomes another character in the poem, and Mr. Flood handles it just like a baby "tenderly, fearing it may awake"; because of all people, he knows best "most things break". Time has broken him by taking away those with whom he had any meaningful association.

Overwhelmed by old age, loneliness, and nostalgia for an honourable past full of friends who are dead now, Mr. Flood resumes mirthful drinking to ease his troubles:

"Only a very little, Mr. Flood

For auld lang syne. No more, sir; that will do."

So, for the time, apparently it did,

And Eben evidently thought so too;

For soon amid the silver loneliness

Of night he lifted up his voice and sang,

Secure with only two moons listening,

Until the whole harmonious landscape rang.

His typical New England Puritan spirit, hesitates to drink more, so he has to insist in order to encourage it. The line "Secure with only two moons listening" sounds ironic, playful, and humorous. Could these "two moons" represent the effect of alcoholism on Mr. Flood's mind! Could it be just a sign of old age instability! Is he deliberately creating two parallel worlds: one of hard unbearable reality, and another of lovely soothing illusion! Then why "secure with only two moons"? Was Robinson avoiding the comic influence of a 'third' moon- as the third and fourth "thought" did in "Miniver Cheevy"! It appears that the poet intended to give us this precise impression. Although there are many affinities between Miniver Cheevy and Mr. Flood, yet, Robinson presented the later in a more serious and dignified manner. The tone of the poem itself blends irony, humour, and pathos, but does not slip to the level of comedy. The poem does not revolve around a misconception, but around what an old man misses in life, which is a concrete and serious issue. Hosting his spirit and consoling himself with drink, Mr. Flood goes on singing the New Year's Eve drinking song:

"For auld lang syne." The weary throat gave out,

The last word wavered, and the song was done.

He raised again the jug regretfully

And shook his head, and was again alone.

There was not much that was ahead of him,

And there was nothing in the town below

Where strangers would have shut the many doors

That many friends had opened long ago.

When the landscape echoes the song with him, the poem reaches its climax. This stanza, with its "song being done", indicates symbolically that this intensified experience and life will soon extinguish. The 'open door' is another Robinsonian expression that symbolizes an entrance upon a new world or life. However, since those doors that used to welcome him are closed now, life will soon close too. The last lines are a reminder of the poem's main theme of 'the passage of time', and its role in creating that pathetic state of existence.

The poem is a success. As usual with Robinson, the poem does not contain any moralizing or didacticism. Although the poet blends beautifully his wise asides with Mr. Flood's thoughts, yet, he maintains a great balance of distance and intimacy. Robinson, as Stephen Dunn remarks, shows great skill in portraying Eben Flood ; especially at the end of the poem when he "neither pulls back far enough to position Eben as sufferer, nor does he stay close enough to him to participate sufficiently in his thoughts" (Note 17).

All of the above poems witness for Robinson's well-founded, neat, sharp, lively, eloquent, concrete, and thorough style. The poet gained such power of clarity and vividness from close observation of the concrete experiences of sufferers fighting against the universe, defeated losers, bewildered failures, and embittered dreamers. No matter what weakness, foolishness, and vanity such characters exhibit, Robinson never makes fun of their catastrophes; but always approaches them with the sympathy of a fellow sufferer in misfortune. He 
usually spots their shattered hopes and degradation, without losing sight of the distinctive characteristics of each of them.

Since Robinson did not intend to teach or preach in his poetry (Note 18), we should not expect him to offer answers to these sufferers, or present them with clues and ready solutions to sooth their pain. He merely observes, recognizes, and sympathizes with their tragedies. J. V. Comings remarks that "Robinson kept asking the inadmissible question, What is it all about? especially considering the pain. That it was unanswerable he thought guaranteed the question" (Note 19). Robert Frost, too, believed that Robinson withheld the answers intentionally; otherwise, he would have told his readers if he had wanted (Note 20). What is actually witty is leaving the reader to believe that there exist so many truths about any given situation. This will motivate the mind to consider the many possible solutions; depending on the various available ways of thinking. Such an enigma would definitely result in an incredible richness of suggestibility. Our minds will be open to a variety of options that roam in all directions. In fact, the intolerable questions raised and the unforgettable truths tackled by the poet, seem more gratifying than a resolving judgment at the end of any of these poems.

\section{Conclusion}

Edwin Arlington Robinson was one of the most prolific Modern American poets (Note 21). He began writing poetry during a very critical period of America's history. Although he did not attain the recognition he deserved, yet, so many famous literary figures regarded him as one of the unfailing poets of his age. Allen Tate referred to Robinson as" The most famous of living American poets" and the writer of "some of the finest lyrics of modern times"(Note 22). Robert Frost described him as "The prince of heartachers" who" asserted the sacred right of poetry to lean its breast to a thorn and sing its dole fullest"(Note 23). Louis Coxe quotes other writers saying that Robinson "is the major American poet of our era, with only T.S.Eliot as a peer" (Note 24). Warner Berthoff even goes further to say that "Modern poetry in the United States begins with Robinson's volumes of 1896 and 1897, The Torrent and The Night Before, and The Children of The Night"(Note 25).

Although not an innovator in forms of poetry, Robison was a developer. Instead of the highly polished experiences common to the poets of his time, Robinson made man's ordeal the moral centre of his poetry. He dealt with modern issues such as alienation, the complexity of man's psychology, the wasteland of human aspirations, and the unexpected turn of life's events; which are all tendencies that many modern young poets share with him nowadays. Robinson himself once told Esther Willard "he was, perhaps, two hundred years in advance of his time" and "that his habit of understatement, his absorption in the unconscious and semi-conscious feelings and impulses of his characters were the qualities in which he was unlike his contemporaries" (Note26).

In most of Robinson's best poems, including the short ones dealt with above, he attempted to depict the common American failures and treat their life experiences as a fit subject for poetry. He considered lives of entrapped spirits lost in the swarming of life; people burned by the hellish agony of isolation that turned them either suicidal or apathetic, and of the tormented who endure stoically when age's unavoidable plights occur. His chief quality is an excellence of portrayal. The poet James Dickey has written, "No poet ever understood loneliness or separateness better than Robinson" (Note 27). The distress at the end of each poem is caused by the fact that these characters were unable to put their fingers on the real problem in time to save themselves.

Yvor Winters affirms, in an article entitled "A Cool Master", that many modern American poets are indebted to Robinson's revival of the New England tradition (Note 28). Josephine Miles believes, as well, that "Much of his (Robinson's) terminology has been used intensively by the poets of the mid-twentieth century....Robinson foreshadowed the modern poet's connotative, implicative, nostalgic sense of beauty in the world today"(Note 29).

Among the many admirers of Robinson's poetry was President Theodore Roosevelt, who, in an act of patronage, granted the poet a job at a New York City customhouse in 1905, where Robinson worked until 1909.

Robinson won three Pulitzer Prizes; the first in 1921 for his Collected Poems, the second in 1924 for The Man Who Died Twice, and the third in 1927 for Tristram; which was the third and last book in his Arthurian series. In 1929, he published Cavender's House, and was awarded the Gold Medal of the American Institute of Arts and Letters, for his accomplishments in poetry.

He died of stomach cancer in New York City on April 6, 1935.

\section{References}

Bates, Esther Willard. (1944). Edwin Arlington Robinson and His Manuscripts. Waterville, Maine: Colby College Library. 
Berthhoff, Warner. (1965). The Ferment in Poetry. New York: The Free Press.

Clark, Harry Hayden. (1944). Thomas Paine. American Book Company, New York.

Crowder, Richard. (1946). South Atlantic Quarterly, xlv, January.

Dunn, Stephen. Modern American Poetry. Retrieved from http://www.english.illinois.edu/maps/poets/m_r/robinson/about.htm

Hubble, B. (ed.) (1936). American Life in Literature. Harper and Brothers.

Miller, James E., Jr. (1991). The United States in Literature. Scott, Foresman and Company: Glenview, Illinois.

Murphy, Francis. (1970). Edwin Arlington Robinson: A Collection of Critical Essays. Prentice- Hall, Inc., Englewood Cliffs, N. J.

Robinson, Edwin Arlington. (1935). King Jasper. New York: The Macmillan Company.

Spindler, Michael. (1983). American Literature and Social Change. London: The Macmillan Press, Ltd.

Southworth, James G. (1950). Some Modern American Poets. Great Britain: Basil Blackwell, Oxford.

Thompson, Eileen. (1944). The American Experience. Prentice Hall, Englewood Cliffs: New Jersey.

Thurley, Geoffrey. (1977). The American Moment: American Poetry in Mid- Century. London: Edward Arnold Ltd.

Tilak, Ragbukul. (2002). Ralph Waldo Emerson: Essays and Poems. India: Rama Brothers Ltd.

Untermeyer, Louis. (ed.) (1962). Modern American Poetry. New York: Harcourt, Brace \& World, Inc.

Notes

All quotations of Robinson's poems are taken from: Louis Untermeyer, ed., Modern American Poetry, (Harcourt, Brace \&World, Inc., 1962), pp.116-138.

Note 1. Harry Hayden Clark, Thomas Paine, (American Book Company, New York, 1944), p.49.

Note 2. Geoffrey Thurley, The American Moment: American Poetry in Mid-Century, (London: Edward Arnold Ltd., 1977), p.4.

Note 3. Richard Crowder, "Emergence of E. A. Robinson," South Atlantic Quarterly, XLV (January 1946), p.89.

Note 4. Michael Spindler, American Literature and Social Change, (London: The Macmillan Press, Ltd., 1983), p. 156.

Note 5. Walt Whitman, "Democratic Vistas", American Life in Literature, vol, 3, ed. By B. H. Hubbell, (Harper and Brothers, 1936), pp.104-105.

Note 6. Louis Untermeyer, ed., Modern American poetry, (New York: Harcourt, Brace \&World, Inc., 1962), p. 115.

Note 7. Francis Murphy, Edwin Arlington Robinson: A Collection of Critical Essays, (Prentice- Hall, Inc., Englewood Cliffs, N.J., 1970), p. 4.

Note 8. Ragbukul Tilak, Ralph Waldo Emerson: Essays and Poems, (New Delhi: Rama Brothers Ltd., 2002), p. 31.

Note 9. James E. Miller, Jr., et al, The United States in Literature, (Scott, Foresman and Company: Glenview, Illinois, 1991), p. 293.

Note 10. Edwin S. Fussell, "One Kind of Traditional Poet", in Edwin Arlington Robinson: A Collection of Critical Essays, ed., Francis Murphy, p. 101.

Note 11. James Dickey, "Edwin Arlington Robinson: The Many Truths", in Edwin Arlington Robinson: A Collection of Critical Essays, ed., Francis Murphy, p. 82.

Note 12. Robert Frost's "Introduction" to Robinson's King Jasper, (New York: The Macmillan Company, 1935), p.x.

Note 13. James Dickey, "'Edwin Arlington Robinson: The Many Truths", p. 80.

Note 14. Louis O. Coxe, "E. A. Robinson: The Lost Tradition", in Edwin Arlington Robinson: A Collection of Critical Essays", ed., Francis Murphy, pp.64-65. 
Note 15. Stephen Dunn, Mr. Flood's Party", Modern American Poetry, http://www.english.illinois.edu/maps/poets/m_r/robinson/about.htm

Note 16. William Pratt, Ibid.

Note 17. Stephen Dunn, Ibid.

Note 18. Francis Murphy, Edwin Arlington Robinson: A Collection of Critical Essays, p.4.

Note 19. Ibid.

Note 20. Robert Frost, "Introduction" to Robinson's King Jasper, p.x.

Note 21. James G. Southworth, Some Modern American Poets, (Great Britain: Basil Blackwell, Oxford, 1950), p. 28 .

Note 22. Louis O. Coxe, "E. A. Robinson: The Lost Tradition", Murphy, p.60.

Note 23. Robert Frost, "Introduction" to King Jasper, p.l x.

Note 24. Louis O. Coxe, p.75.

Note 25. Warner Berthhoff, "The 'New' Poetry: Robinson and Frost", in The Ferment of Realism, (New York: The Free Press, 1965), p. 265.

Note 26. Esther Willard Bates, Edwin Arlington Robinson and His Manuscripts, (Waterville, Maine: Colby College Library, 1944), p.3.

Note 27. Eileen Thompson, The American Experience, (Prentice Hall, Englewood Cliffs, New Jersey, 1994), p. 537.

Note 28. Yvor Winters, "A Cool Master", in Murphy, pp.8 -14.

Note 29. Josephine Miles, "Robinson's Inner Fire", Murphy, p.115. 